\title{
Application of Restorative Justice in the Settlement of Criminal Cases of Fraud and Embezzlement: Investigation Level
}

\author{
Ismawansa Ismawansa ${ }^{1,{ }^{*}}$ Madiasa Ablisar ${ }^{2}$, Alvi Syahrin ${ }^{2}$
}

\author{
${ }^{1}$ Doctoral Program in Law, Faculty of Law, Universitas Sumatera Utara \\ ${ }^{2}$ Professor of Criminal Law, Faculty of Law, Universitas Sumatera Utara \\ Email: ismawansa67@gmail.com
}

\begin{abstract}
The purpose of restorative justice applied in the settlement of criminal cases is to bring justice back to its rightful place. Both the perpetrator and the victim forgive each other and promise not to sue each other again in the future. The same is true for law enforcement officers, the Indonesian National Police, as the gateway to the start of criminal investigations. By making peace between the perpetrator and the victim through deliberation, it is hoped that, among other things, can reduce the number of prisoners in both the Correctional Institution and the State Detention Center; remove the stigma or stamp of criminality and return the perpetrators of crimes to ordinary people; criminals can realize their mistakes, so they don't repeat their actions; reduce the workload of the police, prosecutors, correctional institutions, courts, and correctional institutions; save state finances; The perpetrator does not feel a sense of revenge because the perpetrator has been forgiven by the victim, the victim quickly gets compensation, community empowerment in crime prevention, and reintegration of criminals into society. It should be in the implementation of restorative justice or case settlement outside the Criminal Justice System, no longer specifically for minor criminal cases, but also includes cases such as humiliation, persecution, fraud and embezzlement, negligence resulting in injury, unpleasant acts, even theft, and gambling. As for the problems, namely: settlement through restorative justice eliminates criminal acts, or not. Normative legal research is applied in this paper. The results of the study show that: The settlement of criminal cases of fraud and embezzlement through restorative justice does not eliminate criminal acts. It is recommended that the criminal policy for resolving cases must be changed, not retaliating for actions but recovering the losses caused to the litigants.
\end{abstract}

Keywords: Restorative Justice; Fraud; Embezzlement; Investigation

\section{INTRODUCTION}

\subsection{Background}

Criminal procedural law instruments and the criminal system in Indonesia formally regulate the procedure for the settlement of criminal cases. However, it is known that in practice it is often used as a repressive tool only by law enforcement officers. While the fundamental problem faced by the community is full social control through efforts to protect life and property by every member of the community and to realize the desired social order and is described through order, propriety, and harmony. This can only be realized if the government can implement the law to create a sense of justice in society.[1] Justice is an object that is desired, demanded, and fought for by anyone.[2]
The restorative justice approach in resolving criminal cases is usually known to child perpetrators.[3] The special criminal justice system for children certainly has a special purpose for the future interests of children and society which contains the principles of restorative justice, the definition of restorative justice itself is not uniform, because there are many variations of models and forms that develop in its application. There are many terms used to describe the concept of restorative justice, such as communitarian justice, positive justice, relational justice, reparative justice, and community justice.[4]

In realizing justice, it is very important to know the nature of someone who is a victim in a criminal case. According to Nils Christie, there are six attributes to determine the identity or identity of a victim of a certain crime, including 1) "The victims are weak about the 
offender, 2) The victim is, if not acting virtuously, then at least going about their legitimate, ordinary everyday business; 3) The victim is blameless for what happened; 4) The victim is unrelated to and does not know the stranger who has committed the offense; 5) The offender is unambiguously big and bad; 6) The victim has the right combination of power, influence or sympathy to successfully elicit victim status without threatening (and thus risking opposition from) strong countervailing vested interest".[5]

Based on Nils Christie's explanation above, it can be understood that the real victim must get sympathy and justice, this can be felt if the settlement of criminal cases is carried out through restorative justice. The main principle of resolving criminal acts through a restorative approach is a settlement that must be able to penetrate the hearts and minds of the parties involved in the settlement process to understand the meaning and purpose of doing recovery and the form of sanctions applied is sanctions that are restoring or preventing.[6] While the punishment system is applied as a reaction to the actions of someone who violates legal norms. The perpetrators of crimes are considered to have no regard for the security and rights of others as well as the interests of the victims, the ultimate goal of a punishment is to provide a deterrent effect, order, security or to create the rule of law.

This restorative justice approach can be applied to criminal acts of fraud and embezzlement with perpetrators other than children, but everyone. At Polrestabes Medan, it is often implemented with a peace process between the Reporting Party and the Reported Party. After the peace process has been successfully pursued, the complainant then submits a letter of revocation of the complaint. Then based on the existence of peace and the revocation of the complaint report, Polrestabes Medan investigators followed up by conducting a case title to stop the investigation of the case.

The birth of the idea of the concept of restorative justice or restorative justice as a form of the alternative settlement emerged as a response to the performance of the traditional/conventional criminal justice system, which has characteristics, among others: 1) "The legal apparatus (police, prosecutors, courts), correctional institutions) on behalf of the state for the public interest/community (victims), lawyers/advocates on behalf of the perpetrators, without the direct involvement of the community, perpetrators, and victims or without the active role of the parties involved in the crime to solve their own problems; 2) that the result of the decision (output) is more likely to be retaliatory or punitive rather than giving a "win-win solution" (beneficial to both parties) by the will of the parties, and 3) the perceived justice is retributive (emphasizing justice on retaliation) and restitutive (justice that emphasizes based on compensation), and does not think of ways to provide restorative justice that can be felt thoroughly by all interested parties (stakeholders)".[7]

The reality of community social life, apart from law enforcement carried out by the criminal justice function, turns out that cases of law violations at least involving disputes between citizens are resolved informally by social institutions or individual citizens (neighbors) and even by police officials such as persecution. Thus, a criminal act is not processed until the court.[8] Crimes that are not processed until the judicial stage has put forward the principle of restorative justice in their settlement.

According to Rachmat Aribowo, that: "In its implementation, such practice no longer only recognizes minor criminal cases but also includes cases such as humiliation, persecution, fraud and embezzlement, negligence resulting in injury, unpleasant acts, even theft, and gambling".[9]

Based on the research of Fridoki, O., that at the Medan Polrestabes, cases of fraud and embezzlement are often resolved using a restorative justice approach. Fridoki's research shows that there are 3 examples of cases raised and all of them ended in peace and the revocation of the complaint report.[10]

The ultimate goal of this restorative concept is to reduce the number of prisoners in prisons; remove the stigma or stamp and return the perpetrators of crimes to normal human beings; criminals can realize their mistakes, so they don't repeat their actions and reduce the workload of the police, prosecutors, prisons, courts, and correctional institutions; saving state finances does not create a feeling of revenge because the perpetrator has been forgiven by the victim, the victim quickly gets compensation; empowering communities in overcoming crime, and reintegration of criminals into society.[11]

Based on the description above, the paper entitled: "Application of Restorative Justice in the Settlement of Criminal Cases of Fraud and Embezzlement: At the Investigation Level", deserves to be studied further.

\subsection{Research question}

This paper aims to examine the main problems regarding the application of restorative justice at the level of investigation in the settlement of criminal cases of fraud and embezzlement. These problems can be formulated as follows: How to apply restorative justice in solving criminal cases of fraud and embezzlement: at the investigation level.

\section{METHOD}

The above problems were analyzed by using a case study approach. Cases as secondary data which is the primary source of legal material were obtained from the 
Criminal Investigation Unit Investigator of the Medan Polrestabes. Collecting data using field research, using in-depth interviews without an interview guide to Police Investigators. Qualitative data analysis with inductive conclusions.

\section{RESULTS AND DISCUSS}

\subsection{Criminal Law Policy in the Application of Restorative Justice in the Settlement of Criminal Cases}

Based on the theory put forward by Gerardus Petrus

Hoefnagels, crime prevention policies can be simplified

in two ways. First, the penal policy, which is commonly referred to as the "criminal law application". Second, a non-penal policy consisting of "prevention without punishment" and "influencing views of society on crime and punishment (mass media)".[12]

Efforts to prevent crime and enforce the law through the means of "penal" have several weaknesses, shortcomings, and limitations. It should be balanced with non-penal efforts that must always be explored, utilized, and developed. Exploring and developing non-penal efforts through police activity programs that are oriented towards community service is clearly a natural thing; it is even a necessity because this is also a juridical task or "mandate" which is also outlined by law for the National Police.[13]

Pieter G. Hoefnagels' opinion in Marlina indirectly shows that the penal route or criminal route is not the only way to prevent crime. Pieter G. Hoefnagels in Marlina admits that non-penal ways can be used to overcome crime. The concepts of diversion and restorative justice are two concepts of resolving criminal acts that protect perpetrators and victims. The two concepts in the settlement involve the consent of the victim, the perpetrator, and elements of the community.[14]

The approach to crime prevention efforts must be carried out integrally because the problem of crime is humanitarian and social. The approach only through the application of criminal law alone is not appropriate, because the application of criminal law has limitations.[15]

Restorative justice is a settlement process carried out outside the Criminal Justice System (Criminal Justice System) by involving victims, perpetrators, victim supporters, perpetrators supporters, and the community as well as parties with an interest in a criminal act that occurred to reach an agreement and settlement. Restorative justice is considered a new way of thinking/paradigm in viewing a crime committed by a human being. The concept of restorative justice has a basic understanding that crime is an act against people or society and is related to violations as a violation of legal norms.[16]

Violations committed not only damage the legal order (lawbreaking) made by the state but also damage the social order (society value). Crimes involve the interests of the wider community and the state, this opinion was put forward by Howard Zehr in 1990. Even though criminal acts have damaged the order of community values, but still the central problem for criminal acts committed is the problem of the violation must have been listed in the state law (legal state) and the act is declared a crime.[17]

According to the view of the concept of restorative justice, the handling of crimes that occur is not only the responsibility of the state but also the responsibility of the community. The concept of restorative justice is built on the understanding that the losses incurred by the crime will be recovered, both the losses suffered by the victims and the losses borne by the community.[18]

The implementation of the concept of restorative justice provides many opportunities for the community to play an active role in solving criminal problems. The concept of restorative justice has a framework of thought to find alternative solutions to criminal cases committed without criminal penalties. Alternative solutions are carried out in an effort to create humane justice.[19] The settlement is carried out while still giving the rights of each perpetrator and victim in mediation as the center of the implementation of restorative justice.

In a criminal case of fraud and embezzlement that uses the concept of restorative justice, the role and involvement of community members are very useful and important to help correct errors and irregularities that occur around the community concerned in resolving the case. The settlement with a restorative justice system is expected so that all parties who feel aggrieved will be recovered and there will be appreciation and respect for victims of a crime. Respect is given to the victim by requiring the perpetrator to recover from the consequences of the crime he has committed. The recovery carried out by the perpetrator is in the form of compensation, social work, making repairs, or certain activities by a joint decision that has been agreed upon by all parties in the meeting held.[20]

The implementation of restorative justice cannot be separated from the discretion of the police. Based on the provisions of Article 2 of the Police Law, it can be clearly seen that the Police in their position as law enforcement officers have the function of enforcing the law in the field of judicial, preventive, and repressive tasks. Thus, with the discretionary authority in the judicial field as stated in Article 18 paragraph (1) of the National Police Law, that: "For the public interest, the officers of the State Police of the Republic of Indonesia in carrying out their duties and authorities can act according to their own 
judgment". Of course, in carrying out these actions, it must be by Article 4 of the Police Law, namely by upholding human rights.

Then, the term "police discretion" according to Article 15 paragraph (2) letter $\mathrm{k}$ of the Police Law is known as "other powers". According to Article 16 paragraph (1) letter 1, it is known as "other actions according to the law that is responsible", and according to Article 7 paragraph (1) letter $\mathrm{j}$ of the Criminal Procedure Code known as "any action according to the law that is responsible".

The duties of the police, especially the act of investigation and investigation, the act of "police discretion" must meet the following requirements: First, "Not contrary to a rule of law". That is, running by positive law and other applicable laws in the place where Police Discretion is taken by an officer. In the legal system in Indonesia, there are four sources of law, including state law or positive law, customary law, religious law, and customs. Second, in line with legal obligations that require such actions to be carried out. That is, the actions taken are regulated in certain rules as a legal obligation to be enforced. Third, it must be appropriate, reasonable, and included in the work environment. That is, it is acceptable with common sense for the environment in which the action is taken. Fourth, proper consideration based on compelling circumstances. That is, in its implementation or delivery method in the field, it is carried out based on events that only occur at certain times (emergencies) without in-depth observation or research about what the decision was made. Fifth, respect human rights. That is, by the provisions of human rights and does not violate the provisions of these human rights.[21]

Article 16 paragraph (1) and Article 18 of the Police Law and Article 7 paragraph (1) sub j of the Criminal Procedure Code if there are no clear and firm restrictions, the exercise of discretion can be misinterpreted which can lead to acts of irregularities in police discretion.

As for the application of "police discretion" that cannot be prosecuted before the law, of course, is the discretion of the police which has a legal basis to exercise discretion by Article 18 of the Police Law and Article 7 of the Criminal Procedure Code. However, of course, this authority can be exercised with certain considerations as limitations. So, the discretionary authority is now unlimited. Discretionary action by the police is limited by: "The principle of necessity, that the action must be absolutely necessary; Actions taken are strictly in the interest of police duties; The principle of purpose, that is the most appropriate action to eliminate a disturbance or the non-occurrence of a concern for greater consequences; The principle of balance, that is taking action, a balance must be taken into account between the nature of the action or target used and the size of the disturbance or the severity of an object that must be acted upon.[22]

The policy steps taken by the police are usually well understood by the functional components in the criminal justice system. especially by prosecutors. According to M. Faal, the policy steps taken by the police are usually based on the following considerations: "The use of local customary law is considered to be more effective than the applicable positive law; Local laws are more accessible to the parties between perpetrators, victims and the community; The policy adopted is more beneficial than simply using the existing positive law; Of their own will; and does not conflict with the public interest".[23]

\subsection{Application of Restorative Justice in the Settlement of Criminal Cases of Fraud and Embezzlement: At the Investigation Level}

Settlement of cases by family deliberation implements the element of forgiveness in the case being handled. The element of forgiveness means that the victim has forgiven the perpetrator, but the element of forgiveness does not eliminate the crime. The element of forgiveness can be the basis for mitigating the judge's decision at the trial level in court.[24]

Law enforcement activities carried out by the Investigators of Criminal Investigation Unit against criminal acts of fraud and embezzlement are not fully carried out under the Criminal Procedure Code. This is because there is law enforcement prioritizing restorative justice and penal restorative justice mediation, especially against criminal acts of fraud and embezzlement.

The application of restorative justice and penal restorative justice mediation is a concept of thought that responds to the development of the Criminal Justice System by focusing on the need for community involvement and victims who feel left out by the mechanisms that work in the current SPP.

Based on the results of interviews with Police Commisioner (Kompol). Rafles Langgak Putra, Head of the Medan Polrestabes Criminal Investigation Unit, obtained information that the reason the Medan Polrestabes Criminal Investigation Unit puts forward the principle of restorative justice against fraud and embezzlement is based on the investigators' direct consideration of the crimes of fraud and embezzlement that occurred. The Medan Police Satreskrim Investigators in applying the principles of restorative justice are based on various considerations, including 1) "Prioritizing the support and healing of victims; 2) The perpetrator of the violation is responsible for what was done; 3) Dialogue between victims and perpetrators to reach understanding; 4) There is an effort to put a large amount of the losses incurred; 5) Offenders must be aware of how not to repeat the crime in the future, and 6) 
The community helps to integrate both victims and perpetrators".

Meanwhile, Penal Mediation is a process of restorative justice in criminal law that is carried out using mediation between the perpetrator and the victim. This is as stated based on an interview with Police Commissioner (Kompol) Rafles Langgak Putra, Head of the Medan Police Criminal Investigation Unit, that: "Penal mediation is a process of restorative justice in criminal law which is mediation between the perpetrator and the victim with the aim of for reparations where the perpetrators repair what has been damaged, the perpetrator-victim conference which brings together the families of both parties as well as community leaders".

Furthermore, penal mediation is a form of dispute resolution out of court (Alternative Dispute Resolution) which is always put forward in civil cases. But that doesn't mean it can't be applied in a criminal law environment. In practice, there are several rules that form the legal standing for the application of penal mediation in Indonesia, including:

First, the Indonesian National Police Letter No. Pol. : B/3022/XXI/2009/SDEOPS, dated December 14, 2009, regarding Case Handling Through Alternative Dispute Resolution (ADR). This letter is a reference for the Indonesian National Police to resolve cases of minor crimes, as regulated in the Criminal Code, especially in Article 205, Article 302, Article 315, Article 352, Article 373, Article 379, Article 384, Article 407, and Article 482. In addition, the letter from the Head of the National Police is effective if a case is still at the stage of the investigation and investigation process. Several points of emphasis in the RI Police Letter, among others: 1) "Trying to handle criminal cases that have small material losses, the settlement can be directed through Alternative Dispute Resolutions; 2) Settlement of cases through Alternative Dispute Resolutions must be agreed upon by the litigants, but if no agreement is reached, it must be resolved by professional and proportional legal procedures; 3) Settlement of cases through Alternative Dispute Resolution must be based on deliberation and consensus and must be known by the surrounding community; 4) Settlement of cases through Alternative Dispute Resolutions must respect social/customary legal norms and fulfill a sense of justice; 5) For cases that have been resolved through Alternative Dispute Resolutions so that other legal actions will no longer be touched."'[25]

Second, the Decree of the National Police Chief No. Pol. Skep/360/VI/2005 concerning the Grand Strategy of the Indonesian National Police 2005-2025, Phase III: Service For Excellence (2016-2025), 9th National Police Chief Promoter Program: More Professional and Fair Law Enforcement, 7th Activity: Easy and Light Case Resolution Through Restorative Justice Approach.[26] Third, the Chief of Police Circular No. SE/8/VII/2018 concerning the Application of Restorative Justice in the Settlement of Criminal Cases. Fourth, the Decree of the Director-General of the Supreme Court of the Republic of Indonesia No. 1691/DJU/SK/PS.00/12/2020 concerning the Implementation of Restorative Justice Guidelines. Fifth, the offense committed in the form of "violations that are only punishable by a fine". Article 82 of the Criminal Code, the authority/right to demand the offense is nullified, if the Defendant has paid the maximum fine for the offense and the costs incurred if the prosecution has been carried out.

In the application of the principles of restorative justice carried out by the Satreskim Polrestabes Medan against criminal acts of fraud and embezzlement, the mechanisms used are: "Pre-Restorative Justice Stages; Stages of the Restorative Justice Process; PostRestorative Justice Stages.

The mechanism mentioned above is a restorative justice mechanism carried out by the Medan Polrestabes Criminal Investigation Unit, so that the number of cases of fraud and embezzlement handled by investigators has actually implemented the principle of restorative justice.

\subsubsection{Stages of Pre-Restorative Justice}

At the pre-restorative justice stage, the process can be seen as shown below:

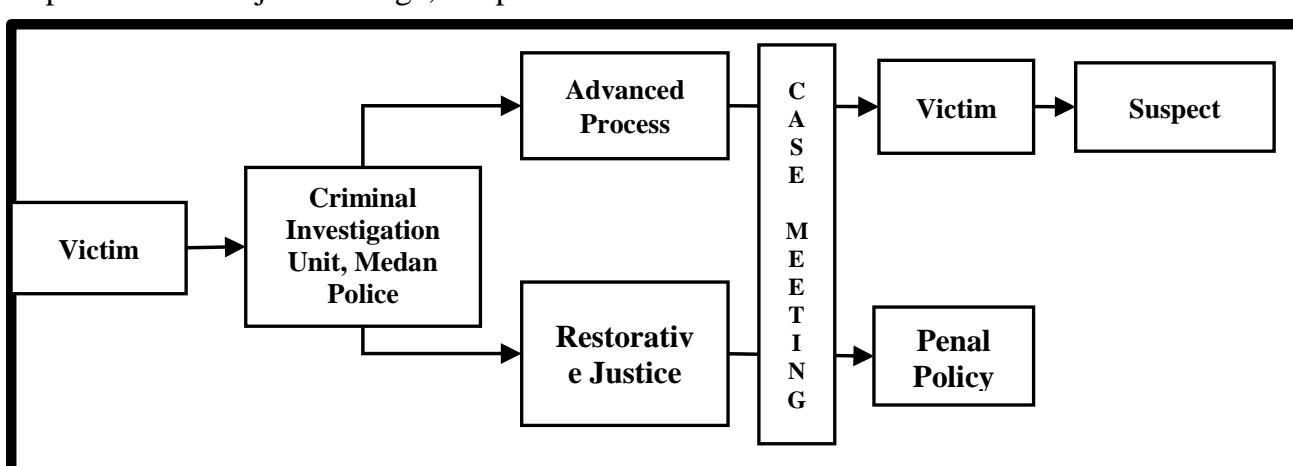

Figure 1 Stages of Pre-Restorative Justice 
Based on Figure 1 above, the stages of pre-restorative justice at the Medan Police Criminal Investigation Unit are as follows: 1) The victim reports to the Medan Police Criminal Investigation Unit Investigator; 2) The investigator will then make an Examination Report (BAP) by summoning all witnesses and confiscate some of the existing evidence; 3) After the Minutes of Examination (BAP) is carried out, and completes the information regarding the cases that have been received, then the investigator will conduct an assessment of the cases he handles whether restorative justice needs to be done or not; 4) If the case continues, the Investigator will hold the case and summon and examine the victim; 5) The investigator will then decide who the suspect in the case is; 6) If the case needs restorative justice, then the investigator will carry out a case title and make a summons as well as mediation between the perpetrator and the victim; 7) As a result of mediation, a joint decision will be obtained which is known as a penal policy.

\subsubsection{Stages of the Restorative Justice Process}

The stages of the restorative justice process carried out by the Medan Police Criminal Investigation Unit are as follows:

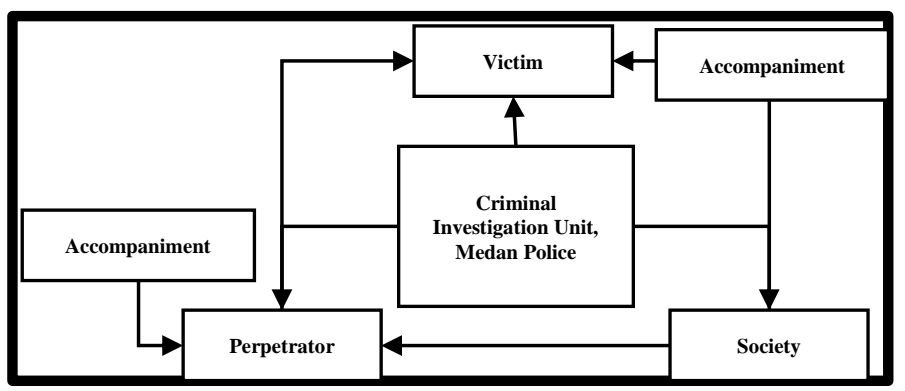

Figure 2 Stages of the Restorative Justice Process.

Based on Figure 2 above, the stages of the restorative justice process at the Medan Police Criminal Investigation Unit are as follows: 1) The reporter/victim and assistance from the Legal Aid Institute (LBH), will be summoned to meet in a mediation room; 2) Then the investigator will open the program and notify the stages of the investigation; 3) After the event is opened by the investigator, the investigator will invite the victim to convey his wishes regarding compensation/compensation, moral and material compensation (if there is a loss); 4) The parties are expected to listen to the information given by the victim; 5) After hearing the statement from the victim, the investigator invites the perpetrator to convey his ability regarding compensation/compensation/moral and material compensation and the reasons for the perpetrator to commit the crime; 6) After the parties provide information, the investigator will provide an opportunity for the victim and assistance from Legal Aid Institution (LBH) to provide their views; 7) After an agreement has been reached between the parties, the investigator will draft a peace agreement between the perpetrator and the victim; 8) If there is no agreement between the investigators, it is only enough to make a resume of mediation activities; 9) The investigator asks the parties to sign a letter of agreement by first asking the perpetrator to fulfill what has been agreed.

\subsubsection{Post Restorative Justice Stages}

The stages of post-restorative justice carried out by the Medan Police Criminal Investigation Unit are as follows: 1) The Peace Agreement is signed by the parties; 2) The Whistleblower shall make a letter of revocation of the police report addressed to the Head of the Criminal Investigation Unit of the Medan Polrestabes; 3) Further examination is carried out to the Reporting Party to confirm whether it is true that there has been a reconciliation; 4) If the reporting party's statement confirms that a peace agreement has been reached by way of deliberation and consensus, then the reporter withdraws all his/her statements that were given during the initial examination, so that the testimony of the victim's witness becomes non-existent as evidence; 5) With the revocation of the complaint report and the revocation of information, the Investigator then submits a proposal for a case title to the Kasatreskrim Polrestabes Medan for a case title; 6) The results of the case title state that there is insufficient evidence in the case because there is no witness testimony from the complainant so that the investigation is terminated; 7) From the case title, it is recommended to the Medan Police Chief to issue a Decision Letter regarding the Termination of Investigation followed by the issuance of an Investigation Termination Order (SP3), so that the case is terminated and will not proceed to further legal proceedings. 
Figure 3 Post Restorative Justice Stages

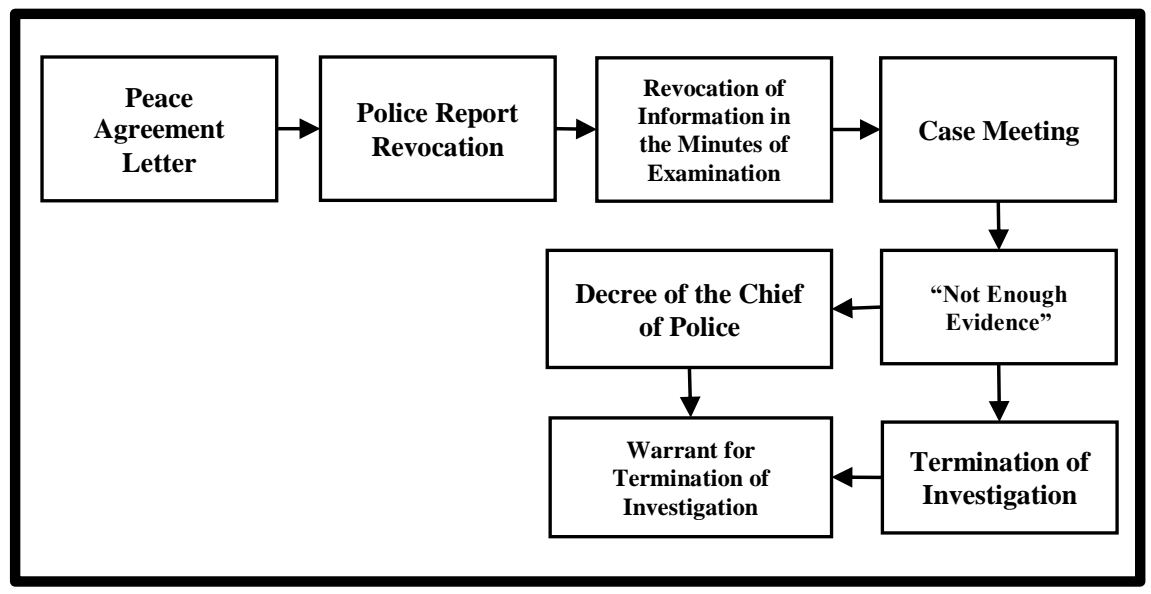

Based on the stages mentioned above, basically, the Medan Police Criminal Investigation Unit investigators act actively to resolve the crime of fraud and embezzlement. The application of the principle of restorative justice carried out by the Medan Police Criminal Investigation Unit aims to consider sociological factors for both perpetrators and victims, so that both parties each get justice.

The principle of restorative justice was originally started as an attempt to rethink the unmet needs in the ordinary judicial process. Restorative justice expands the circle of stakeholders or parties involved in the event or case. Not only the government and perpetrators, but also victims and community members, such as the head of the environment, Babhinkamtibmas, and so on.

A prominent characteristic of the principle of restorative justice is that crime is placed as a symptom of social action and not just a violation of criminal law. Crime is seen as an act that harms others and damages social relations. This is different from the criminal law which has drawn crime as a matter of the state, and only the state has the right to punish, even though indigenous communities can actually impose sanctions.

The application of the principle of restorative justice carried out by the Medan Police Satreskrim Investigators in practice has helped reduce the number of law enforcement cases that have been piling up at the Medan Polrestabes Satreskrim. In addition, no less important is the low cost of law enforcement and the creation of a sense of justice between both parties, both perpetrators and victims. However, the efforts made at this time are still found to be several obstacles, so that the application of the principles of restorative justice that is carried out is not running optimally.

Based on the results of interviews with the Police Commissioner. Rafles Langgak Putra, Head of the Medan Police Criminal Investigation Unit, in implementing the principle of restorative justice, investigators encountered several obstacles. As for the obstacles faced by investigators, among others: First,
"The demands of the victim sometimes exceed the capabilities of the perpetrator/reported; Second, the time required for the application of restorative justice is very short, namely two months after detention; Third, the Perpetrator/Reported is a recidivist in other criminal acts; Fourth, the Perpetrator/Reported was less cooperative towards the victim after the incident; and Fifth, there is a prolonged conflict between the victim and the perpetrator/reported so that the victim does not forgive the perpetrator".

Although several obstacles in the application of restorative justice in handling cases of criminal acts of fraud and embezzlement are often encountered, they do not become a barrier for investigators to implement and promote restorative justice as a settlement of criminal cases of fraud and embezzlement.

In addition to some of the obstacles mentioned above, in practice there are several other obstacles that cause the settlement of cases of criminal acts of fraud and embezzlement by means of restorative justice does not run optimally, namely: the absence of rules/regulations or legal umbrellas as well as formal procedures/mechanisms to accommodate the settlement of criminal cases. criminal justice by means of restorative justice. So that to carry out case resolution using restorative justice investigators from the Medan Polrestabes Criminal Investigation Unit become a dilemma due to several factors in the field, namely: First, "The investigator's concern or fear will be blamed by the investigator's leadership or superiors and be questioned on supervision and examination by the supervisory institution as well as the internal examination of the National Police. using formal procedural parameters; Second, the absence of a legal/regulatory umbrella that regulates and becomes the basis for legitimacy in making decisions/discretions whether based on the principles of restorative justice or other appropriate concepts/approaches; and Third, Apart from the absence of a legal umbrella, the obstacle in implementing the principles of restorative justice or other approach 
concepts is the absence of formal-procedural procedures or mechanisms to implement them".

\section{CONCLUSIONS}

The settlement of cases of criminal acts of fraud and embezzlement through restorative justice at the level of investigation does not abolish the crime because the investigation is only terminated on the grounds that sufficient evidence is not found. The termination of the investigation is stated in the Decision Letter for Termination of Investigation which is followed up by the Order of Termination of Investigation (SP3). The SP3 can be reopened at any time if it is submitted for pre-trial by one of the parties so that with the order of a court decision, investigations of criminal acts of fraud and embezzlement whose investigations are stopped can be reopened.

The urgency of resolving cases by prioritizing the principle of restorative justice is absolutely necessary so

\section{REFERENCES}

[1] Scheb JD, John M., dan Scheb II, John M., 2008, Criminal Law and Procedure, 6th Edition, Belmont: Thomson Learning, hlm. 3.

[2] Wasitaatmadja, Fokky Fuad., 2020, Filsafat Hukum Rasionalisme dan Spritualisme, Jakarta: Prenada Media Group, hlm. 31.

[3] Marlina, 2006, "Pengembangan Konsep Diversi dan Restorative Justice Dalam Sistem Peradilan Pidana Anak di Indonesia (Suatu Studi di Kota Medan)", Disertasi, Sekolah Pascasarjana Universitas Sumatera Utara, Medan.

[4] United Nations (PBB), 2006, Handbook on Restorative Justice Programmes, New York: United Nations Publication, hlm. 6.

[5] Dignan, James., 2005, Understanding Victims and Restorative Justice, Berkshire: Open University Press - McGraw-Hill Education, hlm. 17.

[6] Sarwirini, (2014), "Implementasi Restorative Justice Dalam Penegakan Hukum Pajak”, Jurnal Yuridika, Vol. 29, hlm. 383-384.

[7] Karim, (2016), "Tanggung Jawab Pelaku Pidana Pelanggaran Dalam Perspektif Restorative Justice", Jurnal Yuridika, Vol. 31, (3), hlm. 410-411.

[8] Aribowo, Rachmat., 2013, "Peran Penyidik Satuan Reskrim Polres Samosir Dalam Penanganan Penyidik Tindak Pidana Penganiayaan Pada Wilayah Hukum Polres Samosir", Sekolah Tinggi Ilmu Kepolisian Domisili Akpol Semarang, hlm. 4.

[9] Aribowo, Rachmat., 2013, "Peran Penyidik Satuan Reskrim Polres Samosir Dalam Penanganan Penyidik Tindak Pidana Penganiayaan Pada Wilayah Hukum Polres Samosir", Sekolah Tinggi Ilmu Kepolisian Domisili Akpol Semarang, hlm. 4.

[10] Fridoki, O., 2019, "Penerapan Restorative Justice Dalam Penyelesaian Perkara Tindak Pidana that in addition to saving investigation costs, justice can also be created between perpetrators and victims. In this regard, in order to ensure uniformity in the application of the principles of restorative justice within the Indonesian National Police, a legal norm or rule is needed to ensure the similarity of the actions of Polri investigators in applying the concept of restorative justice to criminal law enforcement, and to provide legitimacy to Polri investigators so that all actions taken are carried out. Restorative justice and the humanist approach do not replace retributive justice. The humanist approach should be implemented since the formulating of a law and is a part of the criminal justice system and the discretion authority of the police investigators is the beginning of the door to the Criminal Justice System to restore justice back to its rightful place.

Penipuan dan Penggelapan di Polrestabes Medan", Tesis, Program Studi Magister Ilmu Hukum Fakultas Hukum Universitas Sumatera Utara, Medan, hlm. 169-184.

[11] Karim, (2016), "Tanggung Jawab Pelaku Pidana Pelanggaran Dalam Perspektif Restorative Justice", Jurnal Yuridika, Vol. 31, (3), hlm. 410-411.

[12] See: Gilling, D. (2005). Crime prevention: theory, policy and practice. Routledge; Schneider, S. (2009). Crime prevention: Theory and practice. Routledge; Wong, D. S. (2016). Restorative justice at different levels of the criminal justice system in China: challenges and paths forward. Restorative Justice, 4(1), 10-26; and Tamanaha, Brian., 2001, A General Jurisprudence of Law and Society, Oxford: Oxford University Press, hlm. 36.

[13] Arief, Barda Nawawi., 2005, Beberapa Aspek Kebijakan Penegakan dan Pengembangan Hukum Pidana, Bandung: Citra Aditya Bakti, hlm. 15.

[14] Marlina, 2006, "Pengembangan Konsep Diversi dan Restorative Justice Dalam Sistem Peradilan Pidana Anak di Indonesia (Suatu Studi di Kota Medan)", Disertasi, Sekolah Pascasarjana Universitas Sumatera Utara, Medan, hlm. 36.

[15] Arief, Barda Nawawi., 2005, Beberapa Aspek Kebijakan Penegakan dan Pengembangan Hukum Pidana, Bandung: Citra Aditya Bakti, hlm. 44-45.

[16] Marlina, 2006, "Pengembangan Konsep Diversi dan Restorative Justice Dalam Sistem Peradilan Pidana Anak di Indonesia (Suatu Studi di Kota Medan)", Disertasi, Sekolah Pascasarjana Universitas Sumatera Utara, Medan, hlm. 45.

[17] Marlina, 2006, "Pengembangan Konsep Diversi dan Restorative Justice Dalam Sistem Peradilan Pidana Anak di Indonesia (Suatu Studi di Kota Medan)", Disertasi, Sekolah Pascasarjana Universitas Sumatera Utara, Medan, hlm. 46. 
[18] Marlina, 2006, "Pengembangan Konsep Diversi dan Restorative Justice Dalam Sistem Peradilan Pidana Anak di Indonesia (Suatu Studi di Kota Medan)", Disertasi, Sekolah Pascasarjana Universitas Sumatera Utara, Medan.

[19] Marlina, 2006, "Pengembangan Konsep Diversi dan Restorative Justice Dalam Sistem Peradilan Pidana Anak di Indonesia (Suatu Studi di Kota Medan)", Disertasi, Sekolah Pascasarjana Universitas Sumatera Utara, Medan, hlm. 46.

[20] Marlina, 2006, "Pengembangan Konsep Diversi dan Restorative Justice Dalam Sistem Peradilan Pidana Anak di Indonesia (Suatu Studi di Kota Medan)", Disertasi, Sekolah Pascasarjana Universitas Sumatera Utara, Medan, hlm. 47.

[21] Mabes Polri, 2002, Buku Pedoman Pelaksanaan Tugas Bintara Polri di Lapangan, Jakarta: Mabes Polri, hlm. 132.

[22] Mabes Polri, 2002, Buku Pedoman Pelaksanaan Tugas Bintara Polri di Lapangan, Jakarta: Mabes Polri, hlm. 132.
[23] Faal, M., 1991, Penyaringan Perkara Pidana oleh Polisi (Diskresi Kepolisian), Jakarta: Pradnya Paramita, hlm. 74.

[24] Fauzan, M., 2015, Peranan Perma dan Sema Sebagai Pengisi Kekosongan Hukum Indonesia Menuju Terwujudnya Peradilan Yang Agung, Jakarta: Prenada Media Group, hlm. 1108. Lihat juga: Sofian, Ahmad., 2018, Ajaran Kausalitas Hukum Pidana, Jakarta: Prenada Media Group, hlm. 275.

[25] Surat Kepolisian Negara RI No. Pol: B/3022/XXI/2009/SDEOPS, tertanggal 14 Desember 2009, perihal: Penanganan Kasus Melalui Alternative Dispute Resolution (ADR).

[26] Gunawan, Budi., 2016, "Tindak Lanjut Penjabaran Program Prioritas dan Kegiatan: Optimalisasi Aksi Menuju Polri Yang Semakin Profesional, Modern, dan Terpercaya Guna Mendukung Terciptanya Indonesia Yang Berdaulat, Mandiri, Berkepribadian Berdasarkan Gotong Royong", Mabes Polri, Jakarta, 15 Juli 2016, hlm. 8-11. 